\title{
Piety and profit; the moral embeddedness of an enterprising community
}

\begin{abstract}
We are interested in how morality can be sustained in entrepreneurial practice. We examine the interesting case of the Hutterites, a communal society who practice community entrepreneurship entrepreneuring by the community and for the community. Arguing that culture provides values and that morals are cultural artefacts - we show how ethics determine the entrepreneurial practices of this remarkably successful entrepreneurial society. Our analysis explains how in this close-knit society, cultural morals and ethics of practice are perfectly aligned, embodied in practice and determine how entrepreneurship is practiced. The result is an economically viable society that preserves its ancient way of life and combines piety and profit. We demonstrate how cultural values shape entrepreneurial practice and how enterprising in this community is a change mechanism, yet also maintains social stability.
\end{abstract}

\section{INTRODUCTION}

This study extends our understanding of collective entrepreneurship by examining how morals and ethics influence the communal enterprising process. Agreeing with Brenkert (2009), we suggest that traditional accounts emphasizing objectivity and rationality may miss the engaged and embedded nature of entrepreneurial endeavors (Granovetter, 1985) and that we should focus more on the virtues that entrepreneurs employ in their moral embeddedness and ethical choices. We critique purely functional economic accounts of entrepreneurship (Anderson, 2015a) and consider the moral and ethical demands placed on entrepreneurs by society and religious culture (Sarasvathy, 2002). Thus, rather than viewing entrepreneurship as simply an engine of change (Johnstone \& Lionais, 2004) and individual entrepreneurs as change agents (Grube \& Storr, 2018) with no moral responsibility beyond economic outcomes; we identify collective entrepreneurship as a socialised practice; one which sustains community values, maintains the community's traditional way of life, and contributes to economic sustainability. 
In theorizing this empirical setting, we relate three concepts; morals, ethics and practices. We distinguish between morals and ethics, arguing that morals are cultural principles held by groups, whilst ethics are embodied, and govern people's practices. Conceptually, we argue that values provide the fabric for culture and morality, but value creation is also the key to understanding the ethics of entrepreneurial practice. Seen this way, we become aware of values as normative guiding principles, a moral compass for the entrepreneurial process. They set out how entrepreneurship should be practiced and provide indicators of responsibilities and obligations what Setten (2004) sees as a moral version of Bourdieu's (1990) habitus. Yet value is also an outcome of the process, demonstrating that values are both inputs and outputs in this entrepreneurial process. Moreover, economic value is important, but subordinate to other values.

We ground our study in an old-world community that operates in Western Canada and the Midwestern United States. This traditional religious society - the Hutterian Brethren (Hutterites) - is a vivid example of a community acting as entrepreneur and as an enterprise; and a juxtaposition of piety and profit. Hutterites combine a strict moral orientation with a long history of enterprising. While many traditional communities have struggled to continue, this community has maintained its traditional way of life. Within this setting, our analysis centered on how the practice of entrepreneuring and the type of value and change produced varies according to the moral values of the society in which it takes place (Steyaert \& Hjorth, 2008). By focusing on ethical practices 'as the objects to be followed', we identify connections to morals and ethics in enterprising activities (Nicolini, 2012). Our guiding research question is - How do morals and ethics influence the practices of community entrepreneurship?

Answering this question allows us to make two contributions to the literature. First, we develop a more morally informed understanding of the process of community enterprising. We 
push forward the perspective of entrepreneurship as a relational practice (Anderson, 2015) and social process (McKeever, Anderson \& Jack, 2014a) by demonstrating how being socially embedded imposes a moral framework on entrepreneurial practices (Bensemann, Warren \& Anderson, 2018). While others have noted a moral dimension of embeddedness, providing behavioural protocols, obligations, and awareness of the responsibilities and benefits of membership (Anderson \& Miller, 2003; McKeever, Jack, \& Anderson, 2014), our account illuminates how ethics enable a community to cohere and to be economically sustained. We analyse a community enacting entrepreneurship together and show how this supports and furthers their values and demonstrates a virtuous cycle of obligation and outcome.

Second, we demonstrate how the alignment of social morals and ethical practices (re)produces a society where entrepreneurial means produce desired ends that sustain both community values and economic sustainability. Our findings show how the Hutterites have done so by practicing community entrepreneurship in a way that protects and defends their traditional way of life. Rindova, Barry, \& Ketchen's (2009) entrepreneurship-as-emancipation standpoint viewed entrepreneurship as an activity enabling individuals to secure freedom from existing social constraints. We extend this view and use our findings to show that community enterprising can be an activity that provides the freedom to maintain such restrictions. Thus, rather than entrepreneurship as emancipation, we conceive community entrepreneurship as maintenance. By incorporating both continuity and change, we show how entrepreneurship has become a way for this community to recreate from and within their society, the society they want to continue. Again, morals and ethics seem to shape outcomes and processes.

We structure the rest of this article by first setting up the argument that self-interest and rationality do not offer sufficient explanations for economic development, never mind social value 
generation (e.g., Ntibagirirwa, 2009). Then, we discuss the social turn of entrepreneurship theory (Hjorth, 2013) highlighting how culture and morals of a society shapes how entrepreneurship is viewed (Dodd, Jack \& Anderson, 2013) and how it is practiced (Fassin, Van Rossem \& Buelens, 2011). We distinguish between morals and ethics, arguing that morals are cultural principles held by groups, whilst ethics are embodied and govern people's practices. Next, we introduce our research setting and the processes of data collection and analysis. Following this, in the findings, we demonstrate how the alignment of social morals and ethical practices (re)produces a society where entrepreneurial means produce desired ends that sustain both community values and economic sustainability. We end the article with a discussion and conclusion.

\section{The ethics of entrepreneurial practice and society}

Sugarman (2015, p. 104) explains how 'neoliberalism is reformulating personhood, psychological life, moral and ethical responsibility' and argues that moral agency takes an economic form. Binkley (2013) similarly describes the neoliberal as independent and selfsufficient, oriented toward pursuing self-interest in a society reconceived in the image of a market. The archetypical modern, neoliberal entrepreneur is homo economicus, free booting, independent, individualistic and responsible only to themselves. Stated simply; the economy is optimized through the entrepreneurial activity of autonomous individuals and human wellbeing is furthered if individuals are free to direct their lives as entrepreneurs.

While these archetypical modern, neoliberal entrepreneurs appear to be effective engines of change, concerns have been raised about how entrepreneurial developments may lack any concern for social or community value (Somerville \& McElwee, 2011) and how the individualistic neo-liberal entrepreneur may even create negative consequences for society (Baumol, 1996). Holland and Shepherd (2013) suggested that although admired, entrepreneurs are often perceived 
as mavericks, willing to do almost anything to succeed, including compromising moral values (see also Fisscher, Frenkel, Lurie, \& Nijhof 2005). Pret and Carter (2017) explain how entrepreneurship's pursuit of commercial objectives may be separate from, and often in conflict with the welfare of community and society.

Recently however, scholars have suggested that self-interest and rationality do not offer sufficient explanations for economic development, never mind social value generation (e.g., Ntibagirirwa, 2009). These arguments have shifted towards understanding entrepreneurship as more of a social process with economic outcomes- the social turn of entrepreneurship theory (Hjorth, 2013; Steyaert \& Katz, 2004). This perspective views entrepreneurship as a relational practice (Anderson, 2015); often a social process (McKeever, Anderson \& Jack, 2014a) but with economic outcomes (Korsgaard \& Anderson, 2011).

Here entrepreneurs and their practices- entrepreneuring- are embedded in society Granovetter, 1985; Jack \& Anderson, 2002). Haugh and Talwar (2016) suggest that the concept of entrepreneuring shifts from considering entrepreneurship as an economic activity that may have social outcomes, to a process with a variety of outcomes. In this social turn, entrepreneurship is both socially constituting (Watson, 2013) and socially constructed (Fletcher, 2006). As socially constituting, the values and meanings associated with entrepreneurship (Hayton, George, \& Zahra, 2002) tell us about the desirability and legitimacy of entrepreneurial behaviours (Anderson \& Smith, 2007). Social constructions of entrepreneurship legitimize only certain types of entrepreneurial practices and operates through what Scott (2007) describes as the cognitive pillar of institutions. Bruton, Ahlstrom and Li (2010) explain that entrepreneurs need to behave and fit in to a desirable or appropriate manner within a socially constructed system, or else they will face 
sanctions for deviating from the accepted norms. These norms are cultural artefacts and represent the moral values of a society (Geertz, 1973).

Accordingly, the practice of entrepreneuring and the value and change produced varies according to the moral values of the society in which it takes place (Steyaert \& Hjorth, 2008). Put differently, being socially embedded imposes a moral framework on entrepreneurial practices (Bensemann, Warren, \& Anderson, 2018). This moral dimension of embeddedness also provides behavioural protocols, obligations, and awareness of the responsibilities and benefits, which accompany membership (Anderson \& Miller, 2003; McKeever, Jack, \& Anderson, 2014). Conceptually, we can construe these practices as virtue ethics (Crockett \& Anderson, 2004). Indeed, in some societies, in contrast to neoliberal ethics of individual autonomy, other ethics, such as the ethics of community and divinity are much more prominent (Haidt, Koller, \& Dias, 1993). In the ethic of community, an action is deemed wrong if a person fails to carry out their duty in the structure of the community, while the ethic of divinity sees a person as a divine creature bearing a bit of God within (Ignatow, 2009, p.106). Indeed, Joyner \& Payne (2002) established that good ethics can have a positive effect on firm performance and that managing by values rather than for profit is usually beneficial: Good firms, especially socially responsible firms, do better (Kempster, Maak, \& Parry, 2019).

Culture, through the institutions that represent the values in that society, including the morals of that society, also shapes both how entrepreneurship is viewed (Dodd, Jack, \& Anderson, 2013) and how it is practiced (Fassin, Van Rossem, \& Buelens, 2011). Culture forms the institutions that legitimize entrepreneurial actions in any given society (Bruton et al, 2010). Indeed, some economists are aware of the consequences of neglecting the structures and institutions that foster responsibility for social value. Baumol (1996), for example, demonstrated how different 
societies and economic systems rendered entrepreneurship as productive, unproductive or even destructive (see also Acs, Boardman, \& McNeely, 2013). El Harbi and Anderson (2010) found different types of entrepreneurship were associated with the moral dimensions and structures of societies. Importantly, this perception of moral embeddedness contradicts the neoliberal assumption that what is good for the individual is also necessarily good for society (Haugh \& Talwar, 2016). If the institutions are benign, entrepreneurial agency will tend to create social value. Moreover, this highlights the potential tensions between individual and collective wellbeing (Johnstone \& Lionais, 2004). This is sometimes theorized as an institutional view, where formal and informal institutions form the environment and the conditions within which entrepreneurship is practiced (Anderson \& Ronteau, 2017). Culture forms the institutions that legitimize entrepreneurial actions in any given society (Bruton et al, 2010).

While this suggests that there is a moral dimension to entrepreneurship, there is little empirical work on how it is ethically practiced. Several scholars have noticed this and called for empirical research to explore the topic (e.g., Bryant, 2009; Buchholz \& Rosenthal, 2005; Kibler \& Kautonen, 2016). As Poldner, Branzei and Steyaert (2018, p.154) put it, 'we need to expand the notion of entrepreneuring as an ethical practice'.

\section{Ethics, community and entrepreneurial practices}

We propose a useful conceptual approach to our problem is to consider how values are employed and created in the entrepreneurial process. As Joyner and Payne (2002) explain, values are the core set of beliefs and principles deemed desirable by groups of individuals and these values are derived from one's membership in a culture (Geertz, 1973). Seen this way, we become aware of values as normative guiding principles, a moral compass in the entrepreneurial process. They set out how entrepreneurship should be practiced, providing indicators of moral responsibilities 
and obligations - what Setten (2004) sees as a moral version of Bourdieu's (1990) habitus. Yet value is also an outcome of the process. Moreover, the idea of entrepreneurship as a value producing process is helpful for distinguishing types of entrepreneurship (Stam \& van Stel, 2011). By taking account what values shape practice and what sort of value is produced, (economic, social or cultural), we have a guide for a conceptually informed typology of entrepreneurial processes that describes both means and ends (Eckhardt \& Shane, 2003).

Payne and Joyner (2006) define ethics as a system of value principles and the ability to determine right from wrong. Making ethical judgements implies that the decision-maker is concerned with the moral rightness or wrongness of the decision, rather than the legality of the decision. We choose to differentiate morals and ethics. For us, morals operate at a cultural level; what a society or community believes to be right and wrong. Contrastingly, we see ethics as behavioral, enacted and embodied in practices, and operating at an individual level (Bourdieu, 1990; Setten, 2004). Wempe (2005) explains that by differentiating between the two levels of morality, it is easier to reach a better understanding of the problem.

Communities are the social and cultural context for morality, but also the recipients and milieu of entrepreneurial practices (Anderson \& Gaddefors, 2017). Lyons, Alter, Audretsch, and Augustine (2012) explain how communities are self-defining. They consist of members connected by a shared identity; a common language; established roles; shared intellectual, moral, and social values; long-term membership status and established social boundaries. Peredo and Chrisman (2006) explain that communities can act as entrepreneur in pursuit of the collective good, and that community entrepreneurship emerges where there is rich social capital, a history of collective learning and action, pronounced boundedness, collective identity, and a governance model that is participative and democratic (see also Di Domenico, Haugh \& Tracey, 2010; Stevens, Moray, \& 
Bruneel, 2014). The community acts as an entrepreneur when its members collaboratively create or identify a market opportunity and organize themselves to respond to it (Peredo \& Chrisman, 2006). The community acts as an enterprise using the existing social structure of the community as a means of organizing those activities.

This body of work suggests that entrepreneurial accomplishment is not only compatible with the archetypical modern, neoliberal entrepreneur; in fact, entrepreneurship is often practiced by, or with, communities concerned with social or community value. Indeed, prior work shows that communities can construct local opportunities which align with the specific needs and concerns of the community. Key themes in this literature emphasize how community entrepreneurship helps alleviate poverty and disadvantage (Berkes and Adhikari, 2006; Dampha and Camera, 2005; MacLean, Harvey and Gordon, 2013, empowers women (Datta and Gailey, 2012), and sustainably develops and preserves the environment (Korshing \& Allen, 2004; Di Domenico, Haugh, \& Tracey, 2010).

These ideas suggest that community context, morals, and ethics may function as a tool for entrepreneurial activity where ethical practices determine "which ends should be pursued, what should be said and done, and how actions should be carried out" (Gehman, Trevino, \& Garud, 2013, pg. 87). Nonetheless, how morals and ethics influence entrepreneurial practices has not been fully explored or theorised, leaving us to question - How do morals and ethics influence the practices of community entrepreneurship? This question, explored ethnographically, allows us to theorize, in a grounded way, the moral micro dynamics of community enterprising and the seemingly virtuous cycle of moral obligation and outcome. We use a practice-based approach that has recently proved useful in entrepreneurship research (Dey \& Staeyart, 2016) to examine how ethics inform entrepreneurship. In this approach entrepreneurial agency always relates to 
structures; making it conceptually impossible to detach the agent from structure (Mair \& Marti, 2006). Structure and agency are dynamic; structure shapes agency and vice versa (Giddens, 1984). This approach allows us to explain how in this close-knit community cultural morals and ethics of practice are perfectly aligned, embodied, and determine how entrepreneurship is practiced.

\section{SETTING}

The context of our study - Hutterite communities - is a vivid example of a community acting as entrepreneur and of the juxtaposition of piety and profit. They combine a strict moral orientation with a long history of enterprising. Hutterites isolate themselves from mainstream society, but are a close-knit community. They all dress the same, live by a strict moral code, hold all possessions in common, forgo all ambitions of individual wealth accumulation and remain committed to their faith and four hundred year old institutions.

Each colony has 80 to 150 members, typically composed of about 14 families. Each colony is governed by its members with daily decisions made by a board of managers known as the Council of Elders or Front Bench. The board usually includes the minister, second minister, financial manager, farm manager, the German teacher and two or three older males who meet every morning to determine the day's agenda and discuss issues. They decide daily matters such as which members may leave the colony for the day, for what purposes, and with which vehicle.

General meetings, attended by all the confirmed colony members, are where more general issues are discussed and strategic decisions made. The Articles of Association guides decisions and expands upon the rights and duties of the members living in the colony; the obligation to live in accordance with their complete community-of-goods philosophy, the rejection of private property and expulsion as a punishment. This society is completely patriarchal; only male members who are married or are baptized bachelors over the age of 25 have the right to vote. 
All officials, except for the minister, are elected at the general meeting. Their election system is unique and involves each male colony member writing on a slip of paper the name of the male individual who he believes is best for the position. The male member who receives the most nominations is declared elected for the position. Unless for health reasons, this member has no right to refuse the position for which he is elected. Electing the minister is seen as a combination of human choice and divine intervention. In a colony where the minister position is vacant, the process is slightly more complex as the Hutterites believe that God has a say in the matter. The process begins the same, with the members casting a vote on who should become the next minister. After this first round of voting, the names of all the candidates who receive more than five votes are recorded on a slip of paper and the bishop draws one of these names at random, with the name drawn believed to have been chosen by God (Katz \& Lehr, 2012). The minister and assistant minister are elected for life unless they are punished or resign. Other members are elected for two years, but usually serve much longer.

Hutterites oppose two tenets of capitalism; self-interest and private property. According to their worldview, people should help their neighbours and share resources. They are a case of community entrepreneurship (Peredo and Chrisman, 2006), an example of an ethical community whose entrepreneurial way of life is determined by their values. Instead of relating entrepreneurship to economic conceptions of profit-oriented growth, development and transformation (Baumol, 1996), Hutterite communities view entrepreneurship practice as a moral duty and mechanism to maintain a traditional way of life while remaining economically sustainable (Peter, 1987). Through shared beliefs and values, the means and ends of Hutterite entrepreneurship are morally and ethically aligned, almost synonymous. Religiously informed ethics are the way of life for the Hutterites. This uniformity, absence of individualism, and deep concern for the 
community seem an odd vehicle for entrepreneurship as presented in a neoliberal view. Yet, innovation, new businesses and profitability characterise the community, thus presenting an interesting case.

Since arriving in North America, the Hutterites have been an unlikely economic and social success story. In 1931, there were 33 colonies on the western plains of North America, with 3,483 inhabitants (Peter, 1987). By 2002, there were 458 colonies. Today, there are over 485 colonies and over 50,000 members (www.hutterite.org). And, the Hutterites have accrued considerable economic capital. A typical colony is valued at over $\$ 25,000,000$; the total value of all the colonies is over $\$ 13$ billion, yet the Hutterites still live by the same Christian principles their ancestors followed 400 years ago. For example, they maintain a commitment to the tradition of voluntary collectivism or 'community of goods.' This total social equality and the elimination of private property differentiates the Hutterian theology and beliefs from other Anabaptist communities (e.g. Amish, Mennonites) (Hostetler, 1997). Hutterites also regard daily life as a form of worship - their faith and beliefs regulating the practices of their daily lives. They live by a principal of "two worlds," which dictates the spatial seclusion of Hutterite colonies from the structure and culture of non-Hutterite society (Katz \& Lehr, 2012). This doctrine separates the world into two kingdoms: The kingdom of God and the kingdom of the world. For the Hutterites, the colony is a place of salvation that will lead to eternal life in heaven (Janzen \& Stanton, 2010). Consequently, Hutterite colonies offer a rich setting to investigate the moral practices of an enterprising community (Dana, 2010).

\section{METHODS}

Our approach was open-ended and inductive, informed by a broad interest in understanding the communal enterprising process within Hutterite communities. Our ethnographic method 
quickly highlighted the pervasive significance of the socioeconomic context, moral orientation and behaviors of the Hutterites. We came to regard these dynamics as the determining influences on community enterprising. Congruent with ethnographic approaches, the research evolved in a series of phases (Hicks, 1984).

\section{Phase 1: Gaining access}

To investigate and understand the practices involved in communal enterprising in these exemplary settings (Miles \& Huberman, 1984; Stake, 1994) we needed access that would allow us to gain an in-depth understanding (Cresswell, 2013; Glaser \& Strauss, 1967). The first author visited her previously established Hutterite connections from when she worked within the agricultural industry and asked elders what they thought of the idea of studying Hutterite colonies. Encouragingly, they were very supportive. They suggested she connect with a management and accounting organization that worked with almost all the Hutterite colonies in Western Canada. She approached this professional consulting organization and asked them if they would assist us in identifying Hutterite communities that were habitually entrepreneurial. "Intrinsic casework regularly begins with the cases pre-specified ... When one designs a study in the manner advocated by Miles and Huberman (1994) nothing is more important than making a proper selection of cases" (Stake, 2005, p. 243). As we wanted to study cases where the outcome and processes were transparently observable (Stake, 2005) we wanted our sample -

(1) to have initiated new ventures and/or products and be in the process of developing another new product and/or venture.

(2) to be located in Western Canada.

(3) to be willing to engage to have an outsider visit.

The first author contacted the seven colonies that had been suggested, explained the purpose of the research, and asked if they would be interested in participating. Two colonies declined. One mentioned the National Geographic show called "Meet the Hutterites." They were extremely 
unhappy with this show as they felt the colony had been tricked and the show portrayed them in an untrue and unfair light. The other colony simply stated they were not interested. Five colonies invited discussion, then agreed to participate. Each was engaged in traditional agricultural operations (e.g., grain farming, dairy, hogs, chickens), had expanded into a number of new ventures, and was exploring and developing several other opportunities (Table 1). Names and minor details have been changed to protect anonymity and confidentiality.

--- Insert table 1 here please---

\section{Phase 2: Data collection}

Observations. The primary source of data was approximately 18 months of participant observation. The first author spent time in each colony and engaged in a variety of activities, such as butchering chickens, gardening, canning, baking, dishwashing, collecting eggs, teaching in the school and working in the greenhouse. She took part in meals, morning meetings, laundry, meal preparation, financial meetings, wedding parties, prayers and social events. Following the advice of Spradley (1980), she wrote about what we saw and heard; i.e., about the colony members, their activities and sequences of events, and the feelings, thoughts and goals that they articulated.

An initial concern was whether the first-author, being a woman would be able to access the inner workings of such a patriarchal society. Fortuitously, her agricultural education and background proved helpful in helping her gain rapport with the Hutterite men. For example, when checking crops, she identified problem weeds and offered solutions. Being married to an agricultural scientist had kept her on top of the latest seed varieties and happenings in agriculture. She was on top of the latest agricultural advice and suggestions. This concern that being a women would impair access was misplaced. 
Interviews. The observation data was supplemented by semi-structured interviews. These interviews were undertaken with various Hutterite people including the minister, assistant minister, field boss, hog boss, German teacher, teacher, gardener, head cook, financial boss, dairy man as well as external informants. Interviews ranged from 45 minutes to 2 hours. In the early interviews general questions were posed to develop understanding of everyday activities. For example, Can you walk me through a typical day? What do you do? How has the community changed over your life? Have you argued over new ideas and colony traditions? Later interviews became more focused and the questions more specific about practices observed. For example, Can you walk me through the process of creating the spreadmeister? What concerns did community members raise? Why was it supported? While community members were amenable to being interviewed and easy to engage in discussion, they were very uncomfortable about recording, so the interviews notes were taken by hand. Interviewees ranged in age from 20 to 75 years old, both male and female. In addition to these formal interviews, many evenings were spent sitting around with a number of Hutterite members.

--- insert table 2 here please---

Documents and artifacts. Other important sources of data were written material. Key books included the Hutterite Confession of Faith, Hutterites in North America, Gender and Communal Longevity among Hutterites, and Hutterite Society. One community provided us with various historical texts and religious scriptures, ordinances, and the ordinance letters from 19622009 (162 pages). Regularly during discussions, the informant would read a passage from a religious text or refer to one of the ordinances. These texts provided an account of Hutterite culture, beliefs and traditions.

\section{Phase 3: Data analysis}


We used inductive, qualitative methods (Strauss \& Corbin, 1998; Maitlis, 2005; Gioia, Corley, \& Hamilton, 2013). Our analysis was exploratory and interpretive, but informed by the literature about the roles that social context, moral orientation and shared values play in the entrepreneurial process; the constant comparative method (Anderson and Jack, 2015).

The first step of our analysis focused on the sayings and doings within this Hutterite social world. We were guided by some of the sensitizing foci and questions suggested by Nicolini (2012) and noted what community members were saying, what they were doing and with what effects. We analyzed the observation notes, personal reflections, interview notes and commentaries to generate an initial understanding of the data (Wolcott, 1995). Golden-Biddle and Locke (2007) call this expanding interpretive possibilities. As we recognized a combination of behaviors, beliefs, and practices we began to zoom in further on the influence of values and moral obligations on these dynamics. Guiding questions we asked were - What are the mundane concerns which orient different practices? What matters to the Hutterites? What does this practice make available? How are the morals and practices different from elsewhere? What type of collective interests are sustained and perpetuated by a specific practice? This helped us to orient the moral orientation of these practices.

These techniques are the constant comparative method; a constant iteration between data and data and data and theory as a sense making exercise (Anderson \& Jack, 2015). We first ask 'what is going on here?' and then, 'how can we explain it?' Hence, after outlining what was going on we then thought more broadly and began to consider the association between social context, moral orientation and shared values and how they influenced the communal enterprising process. Guiding questions were - How does one activity influence another? How does the moral or value under consideration influence the ethics of practice? In what ways is this influencing the 
enterprising process? In a parallel analysis, we developed chronologies of several enterprising initiatives being developed within these Hutterite communities and identified the various stages of the enterprising process. We began to see how certain dynamics and practices influenced the iterative process of community enterprising.

\section{FINDINGS}

On Hutterite colonies, members shared a commitment to "a way of life" that embodies a non-traditional cultural disposition and moral viewpoint. Unlike most developed societies based on modern ideals of individual autonomy, empowerment and agency, in Hutterite colonies the dominant logic was a shared commitment to community, cradle to grave care, and the lifelong provision of welfare and support. We saw that their ways of doing things and how they construct and maintain a way of life was based on a deeply traditional set of values. Our data reflected how the economic practice of sharing goods, underpinned everyday practices in the Hutterite communities. In order to be Hutterite, which was explained as being "one of God's chosen people in the ark of the colony", Hutterites surrender their individual selves to the community. Salvation was described as "a gift", a status that is bestowed upon those who are faithfully participating in the community of goods: "God ordained that people should own nothing ... but should have all things in common (Riedemann, 1565, quoted in Friesen, 2006, p.119-120). From this moral standpoint, all members expressed a non-negotiable belief that individuals put the community first. Personal wealth was frowned upon, "grasping and collecting material possessions" was morally wrong (Riedemann, 1565, quoted in Friesen, 2006, p.119-120). We were told, "We do not have [personal] bank accounts. Whatever you need, it's always there"(4E). We were told that the imprinting (Jaskiewicz, Combs, \& Rau, 2015) of these communal values begins at the 3rd birthday when a Hutterite child enters preschool and anti-individualistic values are enforced. One member 
commented that while every child is special "no one is unique" (4B). Indeed, we found multiple examples of how the strategy and management was determined by the moral principles of group homogeneity, community of good and material egalitarianism. For example, we observed how meals were eaten together in a communal dining hall located in the middle of each colony. Each house was built identically and laid out to allow equal access to colony structures such as the communal dining hall, school, and church. Every member received the same monthly allowance.

Cradle-to-grave care and support was a central tenet of Hutterite doctrine. The old, the infirm and the ill were taken care of within the commune. The elderly were looked up to because they had contributed to the community in their younger working years. One respondent explained, “We don't put our old folks in homes. We care for them here until they die" (4E). A former Hutterite, now living off the colony, told us: "I sure missed being on the colony when my dad got sick. On the colony I would have had a support system to help care for him" (Ex6). Hutterite colonies enforce a non-negotiable collective moral duty to the community and a set of beliefs which mediates individual and collective practices.

Lifestyle was also characterized by a sense of welfare, support and security. Members commented that they never worried about locking their doors, paying bills, or finding their next meal. Parents commented that they didn't worry about the safety of their children on the colony. We observed how the children were often left to roam unsupervised and unorganized in " $a$ Tom Sawyeresque lifestyle"(3E). Another respondent told us that the colony was "free from worry", "our own little kingdom" and that members didn't have to "manage so many things" (3C). This led us to appreciate how this freedom came at the price of strict adherence to the rights and duties of membership, with summary expulsion being the highest form of punishment. 
Our data also revealed a predisposition towards viewing enterprise and innovation as a means of creating meaning and purpose for colony members. For instance, informants expressed how they were "always thinking about how we can provide jobs for all our people" (4F) and expressed a willing obligation to participate in the collective quest towards improving colony conditions:

"We work hard to create businesses that will support the next generation and the generation after that. I feel good knowing that I am working to create a way of life for our youngsters." (1A)

As a practical manifestation of this search for meaning, we observed members taking apart engines, filtration units and farm machinery in a spirit of invention, improvement and innovation - of which Hutterites were very proud. One respondent told us that on the colony things are done "on instinct and not on paper"(3E), which pointed to how proactive invention can be fostered when one is unconstrained by the need for permission or the possibility of managerial rebuke. Hutterites spoke of how community members didn't acknowledge that there were barriers that could prevent things from being done: “We just don't know it can't be done! We fix things, build things, and create new things"(3D). An excerpt from an observation reflects this disposition:

...one of the young men walks by and the Minister speaks to him in German, then laughs. He explains: "His wife has got on him about changing something in the house that he needs to make it better so now he's headed out to figure out how to do it. We try to make something better." (4F)

We noted that personal, affective, and embodied connection to others' situations was an embedded behavioral protocol- “engrossment'” (Noddings 1988). Community members spoke of how they were motivated to look out and care for each other and the collective. Observations captured how members were accessible, receptive and responsive to one another. We observed how members took a genuine interest in, and showed regard for, the other members' interests, qualities, and life circumstances: 
Observation notes: In the basement, the colony has built a winemaking operation. As we sit testing the wine, Ben starts to talk about a neighbor: "Mike's's oldest son left the colony a year ago. I think Mike's heart broke the day his son left. That is why I think expanding into custom manufacturing would create more jobs and help us get Mark's son back. It would make Mike so happy." (5A)

These points are insights into how the morality of the community shaped goals, decisionmaking and ethical practices of their entrepreneurship. It also shows the intergenerational tension between remaining true to old established traditions and values with remaining relevant to the needs and ambitions of the younger generation.

We now explain how values and beliefs shape the community enterprising process. Drawing on embeddedness as a theoretical lens enables us to understand how membership of a social group shapes action (Portes \& Sensenbrenner, 1993). We identify; 1) community-specific triggers, 2) community approval, 3) community-supported progression and 4) community-focused value creation. We observed how moral values and beliefs explain this community enterprising process, and note the continuous enactment of religious and community ethics. We saw this as community morality informing, shaping, and largely determining process.

Community-specific triggers. The collective entrepreneurial process was triggered by various factors that were seen to threaten or enhance the Hutterite way of life. In Hutterite colonies opportunity recognition was not about identifying commercial opportunities in a detached rational framework; rather we observed how their collectivist values and beliefs led to the identification of opportunities that maintained the purpose and internal coherence of the colony. This sensitivity to the conditions of the community and environment caused members to prioritize the common good over self. We documented numerous examples of ideas emerging because their caring beliefs made members receptive and responsive to one another's interests, qualities and life circumstances 
(Noddings, 1988). Our observations explain how this heightened consciousness and compassion influenced opportunity recognition by compelling individuals to try to alleviate others' problems:

Observation notes: On the manufacturing floor, I notice a funny looking chair in the corner. I ask Mike about it: "It's a rocking chair! Grandma and Auntie were saying how much they loved their rocking chairs. All the elders do. Then they complained that they could not take their rocking chairs from the house. This started us thinking about stackable rocking chairs that would be easy to transport. We played around and that is the result. Some schools approached us and asked if we would make them some. They say the rocking chairs are great for kids who have attention deficit disorder." (5B)

The new rocking chair was not triggered by individual self-interest or a desire for commercial gain; rather, it was a practical response for attending to older members, but later recognized to have a wider application. These instances led to our appreciation of how they saw innovation as opportunity to improve the quality of life in the colony. We were also told how many young adults were leaving the colonies. Elder members told us how they recognized this and actively tried to address the issue by creating new ventures:

"We care about our young people and we care about trying to make them successful in this communal life. We need to inspire them and they need to want to be here. That means we need to have options for them...so they can look around and say there are opportunities for them to feel fulfilled within the community." (1B)

The leaders, and indeed all the community, felt that fellow members should have jobs that they felt good about and provided a sense of purpose. Chronologically tracking the development of a new manufacturing process showed us how an opportunity was formalized because they cared about meeting the needs of a member who wasn't interested in, or skilled in agriculture. The manufacturing boss commented;

"We could see that agriculture wasn't Tim's passion. But we noticed that he was really good with computers. So, we put him to work setting up the computers for the manufacturing floor. He needed the inspiration to live in this community." (3B) 
So, the Hutterite values seemed to be guiding the search for opportunities which would create meaning and fulfillment for colony members. Again, we consistently heard the word 'we' being used in group analysis, discussion and problem solving.

Community approval. When value was recognized in an idea, it was assessed by community leaders and sometimes voted on by the men of the community. Within the Hutterite communities, opportunity development was strongly mediated by their preference towards their socially acceptable practices (Bourdieu, 1990). We noted how opportunities deemed out of moral alignment with their way of life were quickly filtered out. At the decision-making stage, colony members seemed heavily influenced by their religion and traditional worldview, which included strong views on the domestic role of women, the importance of relative isolation, the perceived dark side of modern living and the threat of secularism to their collective existence. This moral checklist resulted in some opportunities being explored, but not developed; "Sure we want to provide work, but not just any jobs. The jobs must fit our lifestyle and give our people a sense of purpose" $(4 F)$. When we questioned this motive, the reply demonstrated a commitment to a simple way of life, “we don't want jobs that will keep us stuck inside all day never seeing the sun”(4B). So morality and lifestyle-fit often prevented more radical and profitable developments: "It might mean the colony is going to make less, but we don't want to compromise our lifestyle" (4F).

We witnessed numerous opportunities rejected. Yet, interestingly we also saw how negative evaluations of opportunities also served to trigger the community to look out for more suitable opportunities. When a decision was made not to pursue a potential opportunity, they returned to searching for other "more appropriate" opportunities. For example, one colony abandoned a very lucrative recycling venture: "We started recycling pop bottles. At first, it was great, but we got too busy. We had to get the women working. This is a no-no, so we shut it down 
and started recycling plastic bags" (2A). However, setting these limits and exiting this recycling venture strengthened opportunity recognition: "This [plastic bag venture] fits our lifestyle better because it doesn't need as many people to work on the floor" (2A). This led us to appreciating how these business decisions also enforced and reinforced established gender stereotypes and limited female participation.

Interesting too, was how decisions were not subjected to financial cost-benefit analysis. A consultant to the colony told us:

"They don't have the mainstream business characteristics that would make them entrepreneurial. I cringe when I see the way money is handled on this colony. It's not about the money. They don't look at opportunities in a regular business-minded way." (Ex3)

Opportunities were thus evaluated for their social value and ability to support their social and cultural independence; an opportunity had to preserve their way of life and provide a social benefit to the community. The "front bench" (board of managers) had the final say on this.

Community-supported progression. Here we noted how socially developed behaviors, linked to belonging in the community and influenced the shape and progression of the entrepreneurial action. We had noted how their social norms allowed them to forgo excessive and (in their opinion) unnecessary displays of manners and processes. For example, the Hutterites rarely say please and thank-you to each other. They don't knock when they enter homes. They don't ask permission. They say what needs to be said in an abrupt and forthright manner. Colony members explained that they just said what they meant in an unfiltered manner, "You don't worry about being polite or hurting other people's feelings because we all know each other so well and trust each other" (3D). Tracking opportunities revealed how their communal beliefs and values promoted what the Hutterites called "oppositing" or challenging, which often pushed forward opportunity development. Oppositing was a form of interpersonal provocation and banter - the 
friendly and playful exchange of teasing remarks: "We say things that get the other thinking. It helps work out the problems"(3E). Provoking was an accepted and daily occurrence. Members did not get angry or upset when others challenged them to try to do something. A member told us how "we love to challenge each other to try and do things because it makes it fun" (4D). Another member suggested "competition can be a good thing, keeps the guys on their toes" (4E). When members are provoked, they are pushed to develop opportunities into new products and ventures, which "fitted" with the potential of the market and the morality of the community. Nonetheless, Hutterite values and beliefs narrow choices and practices in conforming to moral views and the desire to provide meaningful employment. We saw this as morally selective engagement with the seemingly limitless choices of the modern economy.

Failure also drove forward the process. Hutterite community welfare orientation provided a supporting structure where ideas could, and often did, fail. We witnessed projects fail but without embarrassment. We were told that failure was an important byproduct of their success. The communities took pride in things that had not worked, even displaying their failed prototypes. The first failed straw-spreader - "spread-meister," sits proudly outside the blacksmith shop. "It's no big deal when something doesn't work out. It just means you do something differently next time” (1E). Respondents showed an awareness that failure was a source of learning. We were told that Hutterites "have to live and learn", not in a bookish sense, in order to prosper.

Community-focused value. Decisions were made about how much to scale-up and how far to take an opportunity. Our analysis demonstrated how this stage was also impacted by religious socialised embeddedness and moral orientation. While traditional entrepreneurs focus on maximizing shareholder value, we observed how the Hutterites concentrate attention and resources on maximizing the value they create for the community. Again, decisions around whether and how 
to scale up was influenced by commitment to reinforcing their common purposes, bringing moral limits into focus. For example, a decision to scale up a new feed mill venture was first made because it protected one aspect of their way of life. The colony financial boss explained: "For us it's important our guys don't have to be out and away from their families. We expanded the mill to provide jobs on the colony. It is important to us that everyone is home and together" (1A). Yet, as the feed mill grew they reached another decision point; but this time their moral orientation influenced a decision to limit scale. More feed meant more trucks to haul the feed. The financial boss said: "We have decided we don't want too many outside truckers coming and going from the colony. We want to control what our members are exposed to. We aren't going to expand the mill anymore"(1A). This decision illustrates the moral constraints and the preoccupation with maintaining traditional domestic roles and controlling boundaries.

The issues of scale and communitarian morality apply to the structure of the colonies. Members believe that colonies operate best when populations do not exceed 150 people. Expand beyond 150 and it becomes harder to provide jobs with responsibility and independent judgment. Division creates more opportunities, but on a smaller scale. An elder explained: "We need to diversify our new colony. When we split, the mother colony kept the dairy so we were down one entity. We decided to diversify into a new recycling plant" (2B). Furthermore, setting up a new colony creates new supervisory jobs. Several Hutterites described how staying small and flat creates positions where people can feel useful (Nordstrom \& Jennings, 2018):

"When you split off a new colony then all of the sudden you need a whole new group of bosses, a new hog boss, dairy boss, field boss, financial boss. It's a way to give more people important roles, where they can feel like they are making a difference and have some control. They aren't just going to be stuck sweeping a floor their whole life." (3A) 
This process of limiting size has resulted in the Hutterian Brethren including almost 500 colonies today. Yet, their moral commitment to maintaining their traditional way of life has also meant that they turn down opportunities to get bigger (e.g. their recycling plant) because of concerns it may encroach on their traditions and culture.

Moreover, colonies tried to avoid competing against each other. Members spoke about the ways they had found to collude with neighboring colonies so as to avoid competition and ensure that their markets, for instance:

"We have this sort of informal agreement amongst us four colonies in this area that if one of us goes in to something then the other's won't. We have gone into recycling plastic bags so now none of the other colonies will." (2A)

Another informant told us part of the reason they had started into quails was "because no other colony was doing it"(1E). These examples highlight how Hutterites morals inform their ethical practices, and helped to maximize communal value. The moral commitment to neighboring colonies drove some initiatives, but also influenced the decision to turn down potentially profitable undertakings. Table 3 shows how stages of the enterprising process are impacted by embeddedness, morals, and ethics.

--- Insert table 3 here please ---

\section{DISCUSSION}

The Hutterite colonies practiced a form of collective entrepreneurship guided by a deep moral commitment to putting community before self. Holding all wealth in common, and always thinking and acting in the interests of the collective, the Hutterites share risks and rewards across the collective. But this shared enterprising was fundamentally shaped by the moral religious values of the community, resulting in ethical entrepreneurial practices which economically sustained the community, yet enabled them to practice their way of life. Ethical entrepreneurship, imbued with 
their entrenched values and commitment, was the means to this desired end. We noted how their values were implicated in decisions and how their sense of community wellbeing prevailed. Patriarchy and what seemed a subordinate role for the women was part of this value system. Authority and power were vested in a seemingly rigid requirement to conform.

We encountered "a Hutterite life" - an embodied belonging and total acceptance of the moral possibilities and limitations of the community (Holt, 1998; MacLeod, 1987). We saw an underlying commitment to living humbly and communally while foregoing individual wealth. What we witnessed was a bounded community of practices and discourses, a meaning system structured in concordance with the principles of their moral code. Colony members seemed to have traded individual choices and freedoms in return for complete psychological and material security, with perceived rewards and salvation in the afterlife.

We did not meet any individual entrepreneurial heroes, what we encountered was a collectivist entrepreneurial process underpinned by deeply held reciprocity, mutuality and a deeply accepted common purpose. Their purpose was about adaptation and change while remaining culturally and socially stable; entrepreneurship enabled modest economic progression, yet it was also a means of providing for the material and emotional needs of colony members. Respondents understood their ethical practices as engaging in "making the colony work" and providing members with a "meaningful" and "satisfying" existence (Cui, Jo, \& Velasquez, 2016). This view was closely managed, and imprinted in members from a very young age.

Rather than merely seeking profit or income - collective engagement in entrepreneurship led to outcomes which "fitted" with their moral beliefs and ethical lifestyle. Colonies enacted opportunities on Hutterite terms, viewed through a moral matrix of perceived ethical possibilities and impossibilities - for example rejecting opportunities which encroached on work-life balance 
and traditional views of family, including gender roles and responsibilities. This shows that their collective values formed a moral environment influencing the ethics of individual practice (McKeever, Anderson, Jack, 2014b). By adhering to a moral code - the means and ends of Hutterite entrepreneurship are aligned with the religiously informed ethics and become almost synonymous. So, the morals and ethics of Hutterite communities are a type of entrepreneurial value system because they continually orient practices and decisions towards what is best for the common good. Finally, what seems central in the Hutterite entrepreneurial process is their collectivist perspective on entrepreneurship and their moral filters - which consistently aligned entrepreneurial processes with their framework of moral principles. Structures, processes and entrepreneurial practices were aligned by ethics.

\section{Contributions}

Our study extends previous research, often focused on identifying preconditions of community enterprising (e.g., Goetz, Keltner, \& Simon-Thomas, 2010; Miller, Grimes, McMullen, \& Vogus, 2012), to explore how the entrepreneurial process is enacted in context and how group morality influences individual practices (McKeever et al., 2014; Welter, 2011; Zahra, 2007). We contribute by showing that community-based enterprising is "a process in which the community acts entrepreneurially to create and operate a new enterprise embedded in its existing social structure" (Peredo \& Chrisman, 2006, p. 310) and how collective values and beliefs influence the stages we identified in the community enterprising process (Austin, Stevenson \& Wei-Skillern, 2006; Chell 2007; Tracey and Phillips 2007). For instance, the Hutterites ethic of care, combined with the security found within these communities triggered and influenced the enterprising process. We observed how ideas were filtered through a moral lens and opportunities 
were aligned with the collectively understood needs and enacted within the capabilities of the group (Korsching and Allen, 2004; Mele, 2012; Peredo and Chrisman, 2006).

Importantly, this shows how Hutterite values and beliefs represent a moral common ground guiding both the means and ends of their entrepreneurial endeavours. According to Anderson, Dodd, and Jack (2010), these shared values represent a modus operandi - a shared perception of entrepreneurial process, practice and purpose. In the social milieux and cultural orbit of the colonies, we demonstrate how these dynamics are involved in the evolution of the enterprising process (Minniti and Bygrave, 2001). For instance, we showed how the social milieu provides members with the resources and support to fail and iterate and a comfort level that allows them to share and provoke each other. Previous work proposes that community-based entrepreneurs, driven by a community-oriented ethos are embedded in specific pluralistic environments (Pache \& Chowdhury, 2012). We complement that research by illuminating the moral heart and compass that pumps and directs the community enterprising process. Similar to McKeever et. al (2014b) we found that business practices were enmeshed, entangled and engaged with the meanings, the values and identities of the community (Anderson \& Gaddefors, 2016). Because Hutterites live, work, pray and socialise in the fishbowls of their colonies, their "belonging" to the colony was second nature - embodied (Bourdieu, 1990). Extending McKeever et. al (2014b), we found that Hutterite entrepreneurship was much more than social responsibility - it was an ethical manifestation of a deeply held moral orientation. In the routines of everyday life, Hutterites have assembled a particular social vision, while creating and looking for market opportunities to construct the economic basis for furthering the vision (Anderson et al., 2010). As such this work is, to our knowledge, one of the first to morally and ethically contextualize a community's enterprising process. 
We further contribute by demonstrating how the alignment of social morals and ethical practices (re)produces a society where entrepreneurial means produce desired ends that allow them to sustain their community values and traditional way of life. This somewhat paradoxical notion of communal enterprising as a way to maintain a community is intriguing. In contrast to the entrepreneurship-as-emancipation standpoint (Rindova et al., 2009) that views entrepreneurship as an activity enabling individuals to secure freedom from existing social constraints, our findings suggest that communal enterprising, underpinned by a collective moral code can be an activity that provides a 'freedom' to maintain traditional communities. The Hutterites show us how practicing communal entrepreneurship helps them to resist de-culturation and maintain their traditional way of life while progressing economically. This could be seen as a rather special form of emancipation. Yet, pardoxically others might see it as control!

Thus, our study suggests that it takes work to build and keep beating the moral heart that pumps and directs the community enterprising process. However, our findings also illuminate the 'dark side' of this moral orientation in that while it can help keep the community functioning and surviving - it can also hinder business and social innovation. Moreover, our analysis shows that these communities are enterprising but their isolation and strict moral standpoint limits business development and innovation to a basic, local and incremental level.

\section{Limitations and Suggested Directions for Future Research}

We focused on particular Hutterite communities, in one country, and with a limited number of respondents. Favoring depth of understanding over breadth means we cannot claim that we have provided a comprehensive list of all of the mechanisms and practices that impact the communal enterprising process. While our case is indeed "special" (Yin, 2004), our model might be applicable in other contexts and to other communities. For instance, our observations could be 
applicable to family SMEs. Additionally, our findings should be relevant to less 'extreme' communities looking for ways to thrive, economically and socially. Our findings could benefit such communities with arrangements that extend capitalist models. Moreover, we believe our study could be particularly relevant to indigenous communities. As previous scholarship has shown, when capitalist logic is applied to "communities whose lifestyles make no financial sense even if they make cultural sense" (Dana \& Light, 2011, pg. 331) the result has often been the destruction and abandonment of traditional indigenous ways of life (Peredo \& Anderson, 2006). The Hutterites show how virtuous circuits of morals (culture) and ethics (practice) can be aligned in entrepreneurial process, to produce an economically vital society that preserves its ancient way of life.

We suggest that our findings are informative to discussions around community development. The Hutterites have made choices about the boundary between individual choice and collective responsibility, and this boundary is very different from most Western communities. The success of these Hutterite communities provides a reason to pause and consider the potential of, and merits in, a system that leans towards welfare and collective responsibility. Although neoliberal initiatives have improved the lives of some people it has also posed challenges to many communities and individuals. As we struggle with increasing inequality, deeply embedded poverty, and decreasing trust, this Hutterite case opens our eyes to a possible alternative, a way which may be able to better address these issues. We nevertheless acknowledge that the broader applicability of our grounded theorizing remains to be tested. Would we have observed the same level of enterprising if these Hutterite colonies had not been doing well financially? Would we have observed more disruptive innovations within these communities if these colonies loosened some of their social rules, for instance if the women were given more authority and opportunity? 


\section{REFERENCES}

Acs, Z. J., Boardman, M. C., \& McNeely, C. L. (2013). The social value of productive entrepreneurship. Small Business Economics, 40(3), 785-796.

Anderson, A.R. (2015). The economic reification of entrepreneurship: re-engaging with the social. In Fayolle, A. and Riot, P. (Eds) Rethinking Entrepreneurship: Debating Research Orientations, Routledge, Abingdon, chapter 4, 44-56.

Anderson, A.R. (2015a), "Conceptualising entrepreneurship as economic 'explanation' and the consequent loss of 'understanding", International Journal of Business and Globalisation, Vol. 14 No. 2, pp. 145-157.

Anderson, A. R., Dodd, S. D., \& Jack, S. (2010). Network practices and entrepreneurial growth. Scandinavian Journal of Management, 26(2), 121-133.

Anderson, A.R. \& Gaddefors, J. (2016) 'Entrepreneurship as a community phenomenon; reconnecting meanings and place', International Journal Entrepreneurship and Small Business, Vol. 28, No. 4, pp.504-518.

Anderson, A.R. \& Jack, S.L. (2015) "An introduction to the constant comparative", Handbook of Qualitative Research Techniques and Analysis in Entrepreneurship, Neergaard, H. and Leitch, C.M. eds, 15-21.

Anderson, A. R., \& Miller, C. J. (2003). "Class matters": Human and social capital in the entrepreneurial process. The Journal of Socio-economics 32(1), 17-36.

Anderson, A. R., \& Smith, R. (2007). The moral space in entrepreneurship: An exploration of ethical imperatives and the moral legitimacy of being enterprising. Entrepreneurship \& Regional Development 19(6), 479-497.

Anderson, A.R \& Ronteau, S. (2017). Towards an entrepreneurial theory of practice: emerging ideas for emerging economies. Journal of Entrepreneurship in Emerging Economies 9(2),110-120.

Austin, J., Stevenson, H., \& Wei-Skillern, J. (2012). Social and commercial entrepreneurship: same, different, or both? Entrepreneurship Theory \& Practice 30(1), 1-22.

Baumol, W.J. (1996). Entrepreneurship: Productive, unproductive, and destructive. Journal of business venturing, 11(1), 3-22.

Bensemann, J., Warren, L. \& Anderson, A. (2018). Entrepreneurial engagement in a depleted small town: Legitimacy and embeddedness. Journal of Management \& Organization, 1-17.

Berkes, F., \& Adhikari, T. (2006). Development and conservation: indigenous businesses and the UNDP Equator Initiative. International Journal of Entrepreneurship and Small Business, 3(6), 671-690.

Binkley, S. (2013). Happiness as enterprise: An essay on neoliberal life. Albany, NY: SUNY Press 
Bourdieu, P. (1990). The logic of practice. Stanford University Press, Stanford, CA.

Brenkert, G.G., 2009. Innovation, rule breaking and the ethics of entrepreneurship. Journal of Business Venturing, 24(5), 448-464.

Bruton, G. D., Ahlstrom, D., \& Li, H. L. (2010). Institutional theory and entrepreneurship: where are we now and where do we need to move in the future?. Entrepreneurship Theory and Practice, 34(3), 421-440.

Buchholz, R.A. \& Rosenthal, S.B. (2005). The spirit of entrepreneurship and the qualities of moral decision making: Toward a unifying framework. Journal of Business Ethics, 60(3), 307-315.

Bryant, P. (2009). Self-regulation and moral awareness among entrepreneurs. Journal of Business Venturing, 24(5), 505-518.

Chell, E. (2007). Social enterprise and entrepreneurship: Towards a convergent theory of the entrepreneurial process. International Small Business Journal, 25(1), 5-26.

Creswell, J. W. (2013). Qualitative inquiry and research design: Choosing among five approaches. 3rd edition. Sage, Thousand Oaks, CA.

Crockett, C. \& Anderson, A.R., (2004). The Added Value of Virtue. Journal of Research in Marketing and Entrepreneurship, 6(1), 5-17.

Cui, J., Jo, H., \& Velasquez, M. G. (2016). Community religion, employees, and the social license to operate. Journal of business ethics, 136(4), 775-807.

Dampha, A., \& Camera, K. (2005). Empowering Communities through Forestry: Community-Based Enterprise Development in the Gambia. Food and Agricultural Organization (FAO) of the United Nations, Forestry Policy and Institutions Working Paper, 8.

Dana, L.P. (2010). Entrepreneurship and religion. Edward Elgar Publishing.

Dana, L. P., \& Light, I. (2011). Two forms of community entrepreneurship in Finland: Are there differences between Finnish and Sámi reindeer husbandry entrepreneurs? Entrepreneurship \& Regional Development 23, 331-352.

Datta, P. B., \& Gailey, R. (2012). Empowering women through social entrepreneurship: Case study of a women's cooperative in India. Entrepreneurship Theory and Practice, 36(3), 569-587.

Dey, P. \& Steyaert, C. (2016). Rethinking the Space of Ethics in Social Entrepreneurship: Power, Subjectivity, and Practices of Freedom, Journal of Business Ethics, 133(4), 627-641

Di Domenico, M., Haugh, H., \& Tracey, P. (2010). Social bricolage: Theorizing social value creation in social enterprises. Entrepreneurship Theory and Practice 34(4), 681-703.

Dodd, S.D., Jack, S. \& Anderson, A.R. (2013). From admiration to abhorrence: the contentious appeal of entrepreneurship across Europe. Entrepreneurship \& Regional Development, 25(1-2), 69-89. 
Eckhardt, J.T \& Shane, S.A. (2003). Opportunities and entrepreneurship. Journal of management, 29(3), 333-349.

El Harbi, S., \& Anderson, A. R. (2010). Institutions and the shaping of different forms of entrepreneurship. The Journal of socio-economics, 39(3), 436-444.

Fassin, Y., Van Rossem, A. \& Buelens, M., (2011). Small-business owner-managers' perceptions of business ethics and CSR-related concepts. Journal of Business ethics, 98(3), 425-453.

Fisscher, O., Frenkel, D., Lurie, Y. \& Nijhof, A. (2005). Stretching the frontiers: exploring the relationships between entrepreneurship and ethics. Journal of Business Ethics 60, 207-209.

Fletcher, D. E. (2006). Entrepreneurial processes and the social construction of opportunity. Entrepreneurship \& Regional Development, 18(5), 421-440.

Friesen. (2006). Peter Riedemann's Hutterite confession of faith. Herald Press. Waterloo, Ontario.

Geertz, C. (1973). The interpretation of cultures. Basic Books, New York, NY.

Gehman, J., Treviño, L. K., \& Garud, R. (2013). Values work: A process study of the emergence and performance of organizational values practices. Academy of Management Journal, 56(1), 84-112.

Giddens, A, (1984), The Constitution of Society. Cambridge, Polity.

Gioia, D. A., Corley, K. G., \& Hamilton, A. L. (2013). Seeking qualitative rigor in inductive research: Notes on the Gioia methodology. Organizational Research Methods, 16(1), 15-31.

Glaser, B., \& Strauss, A. (1967). The discovery of grounded theory. Aldine Publishing Company, Chicago, IL.

Goetz, J. L., Keltner, D., \& Simon-Thomas, E. (2010). Compassion: An evolutionary analysis and empirical review. Psychological Bulletin, 136(3), 351.

Golden-Biddle, K., \& Locke, K. (2007). Composing qualitative research. 2nd edition, Sage, Thousand Oaks, CA.

Granovetter, M. (1985). Economic action and social structure: The problem of embeddedness. American Journal of Sociology, 91(3), 481-510.

Grube, L \& Storr, V. (2018). Embedded entrepreneurs and post-disaster community recovery. Entrepreneurship \& Regional Development, 30(7-8), 800-821.

Haidt, J., Koller, S.H. \& Dias, M.G. (1993). Affect, culture, and morality, or is it wrong to eat your dog?. Journal of Personality and Social Psychology, 65(4), 613.

Haugh, H.M., \& Talwar, A. (2016). Linking Social Entrepreneurship and Social Change: The Mediating Role of Empowerment, Journal of Business Ethics, 133, 643-658. 
Hayton, J. C., George, G., \& Zahra, S. A. (2002). National culture and entrepreneurship: A review of behavioral research. Entrepreneurship Theory and Practice, 26(4), 33-52.

Hicks, D. (1984). Time-tabling. In R. F. Ellen (Ed.), Ethnographic research: A guide to general conduct. London: Academic Press.

Hjorth, D. (2013). Public entrepreneurship: Desiring social change, creating sociality. Entrepreneurship \& Regional Development, 25(1-2), 34-51.

Holland, D.V \& Shepherd, D.A. (2013). Deciding to persist: Adversity, values, and entrepreneurs' decision policies. Entrepreneurship Theory and Practice, 37(2), 331-358.

Holt, D. B. (1998). Does cultural capital structure American consumption? Journal of Consumer Research, 25(1), 1-25.

Hostetler, J. A. (1997). Hutterite society. Johns Hopkins University Press, Baltimore, MD.

Ignatow, G. (2009). Why the sociology of morality needs Bourdieu's habitus. Sociological Inquiry, 79(1), 98-114.

Jack, S. L., \& Anderson, A. R. (2002). The effects of embeddedness on the entrepreneurial process. Journal of Business Venturing 17(5), 467-487.

Janzen, R., \& Stanton, M. (2010). The Hutterites in North America. Johns Hopkins University Press, Baltimore, MD.

Jaskiewicz, P., Combs, J. G., \& Rau, S. B. (2015). Entrepreneurial legacy: Toward a theory of how some family firms nurture transgenerational entrepreneurship. Journal of Business Venturing, 30(1), 29-49.

Johnstone, H., \& Lionais, D. (2004). Depleted communities and community business entrepreneurship: Revaluing space through place. Entrepreneurship \& Regional Development 16(3), 217-233.

Joyner, B.E. \& Payne, D. (2002). Evolution and implementation: A study of values, business ethics and corporate social responsibility. Journal of Business Ethics, 41(4), 297-311.

Katz, Y., \& Lehr, J. (2012). Inside the Ark: The Hutterites in Canada and the United States. University of Regina Press, Regina, SK.

Kempster, S., Maak, T. \& Parry, K. eds. (2019). Good Dividends: Responsible Leadership of Business Purpose. Routledge.

Kibler, E. \& Kautonen, T. (2016). The moral legitimacy of entrepreneurs: An analysis of early-stage entrepreneurship across 26 countries. International Small Business Journal, 34(1), 34-50.

Korsgaard, S. \& Anderson, A.R. (2011), "Enacting entrepreneurship as social value creation", International Small Business Journal, 29(2), 135-151. 
Korsching, P. F., \& Allen, J. C. (2004). Locality-Based entrepreneurship: A strategy for community economic vitality. Community Development Journal 39(4), 384-400.

Lyons, T. S., Alter, T. R., Audretsch, D., \& Augustine, D. (2012). Entrepreneurship and community: The next frontier of entrepreneurship inquiry. Entrepreneurship Research Journal, 2(1).

Maclean, M., Harvey, C., \& Gordon, J. (2013). Social innovation, social entrepreneurship and the practice of contemporary entrepreneurial philanthropy. International Small Business Journal, 31(7), 747-763.

MacLeod, J. (1987). Ain't no makin' it: Levelled aspirations in a low-income neighbourhood. Westview Press, Boulder, CO.

Mair, J. \& Marti, I. (2006). Social entrepreneurship research: A source of explanation, prediction, and delight. Journal of World Business, 41(1), 36-44.

Maitlis, S. (2005). The social processes of organizational sensemaking. Academy of Management Journal 48(1), 21-49.

McKeever, E., Jack, S., \& Anderson, A. (2014). Embedded entrepreneurship in the creative reconstruction of place. Journal of Business Venturing 30(1), 50-65.

McKeever, E., Anderson, A., \& Jack, S. (2014a). Entrepreneurship and mutuality: Social capital in processes and practices. Entrepreneurship \& Regional Development 26(5-6), 453-477.

McKeever, E., Anderson, A. \& Jack, S. (2014b), "Social embeddedness in entrepreneurship research: the importance of context and community", in Chell, E. and Karatas-Ozken, M. (Eds), Handbook of Research on Small Business and Entrepreneurship, Edward Elgar, Cheltenham, 222.

Melé, D. (2012). The firm as a "community of persons": A pillar of humanistic business ethos. Journal of Business Ethics, 106(1), 89-101.

Miles, M. B., \& Huberman, A. M. (1984). Qualitative data analysis: A sourcebook of new methods. Sage, Thousand Oaks, CA.

Miller, T. L., Grimes, M. G., McMullen, J. S., \& Vogus, T. J. (2012). Venturing for others with heart and head: How compassion encourages social entrepreneurship. Academy of Management Review, 37(4), 616-640.

Minniti, M., \& Bygrave, W. (2001). A dynamic model of entrepreneurial learning. Entrepreneurship theory and practice, 25(3), 5-16.

Nicolini, D. (2012). Practice theory, work, \& organization: An introduction. Oxford University Press, Oxford, UK.

Noddings, N. (1988). An ethic of caring and its implications for instructional arrangements. American Journal of Education, 96(2), 215-230. 
Nordstrom, O., \& Jennings, J. E. (2018). Looking in the other direction: An ethnographic analysis of how family businesses can be operated to enhance familial well-being. Entrepreneurship Theory and Practice, 42(2), 317-339.

Ntibagirirwa, S. (2009). Cultural values, economic growth and development. Journal of Business Ethics, 84(3), 297-311.

Pache, A. C., \& Chowdhury, I. (2012). Social entrepreneurs as institutionally embedded entrepreneurs: Toward a new model of social entrepreneurship education. Academy of Management Learning \& Education, 11(3), 494-510.

Payne, D., \& Joyner, B. E. (2006). Successful US entrepreneurs: Identifying ethical decision-making and social responsibility behaviors. Journal of Business Ethics, 65(3), 203-217.

Peredo, A. M., \& Anderson, R. B. (2006). Indigenous entrepreneurship research: Themes and variations. In C. Galbraith \& C. H. Stiles (eds.), Developmental Entrepreneurship: Adversity, risk and isolation, (pp.253-273). Elsevier, Oxford, UK.

Peredo, A. M., \& Chrisman, J. J. (2006). Toward a theory of community-Based enterprise. Academy of Management Review 31(2), 309-328.

Peter, K. A. (1987). The dynamics of Hutterite society: An analytical approach. University of Alberta, Edmonton, CA.

Poldner, K., Branzei, O., \& Steyaert, C. (2019). Fashioning ethical subjectivity: The embodied ethics of entrepreneurial self-formation. Organization, 26(2), 151-174.

Portes, A., \& Sensenbrenner, J. (1993). Embeddedness and immigration: Notes on the social determinants of economic action. American Journal of Sociology, 98(6), 1320-1350.

Pret, T. \& Carter, S. (2017). The importance of 'fitting in': collaboration and social value creation in response to community norms and expectations. Entrepreneurship \& Regional Development, 29 (7-8), 639-667.

Rindova, V., Barry, D., \& Ketchen Jr, D. J. (2009). Entrepreneuring as emancipation. Academy of Management Review 34(3), 477-491.

Sarasvathy, S. (2002). Entrepreneurship as economics with imagination. The Ruffin Series 3, 95-112.

Scott, R. (2007). Institutions and Organizations: Ideas and Interests. Sage Publications. Thousand Oaks, CA.

Setten, G. (2004). The habitus, the rule and the moral landscape. Cultural geographies, 11(4), 389-415.

Somerville, P. \& G. McElwee. (2011). "Situating Community Enterprise: A Theoretical Exploration." Entrepreneurship \& Regional Development 23 (5-6), 317-330.

Spradley, J. (1980). The ethnographic interview. New York: Holt, Reinhart \& Winston 
Stake, R. E. (1994). Case studies. In N. K. Denzin \& YS Lincoln (eds.), Handbook of qualitative research, (pp. 236-247). Sage, Thousand Oaks, CA.

Stake, R. E. (2005). Qualitative case studies. In N. Denzin \& Y. S. Lincoln (eds.), The Sage handbook of qualitative research, 3rd edition, (pp. 443-466). Sage, Thousand Oaks, CA.

Stam, E. \& van Stel, A. (2011). Types of entrepreneurship and economic growth. Entrepreneurship, Innovation, and Economic Development, 78-95.

Stevens, R., Moray, N., \& Bruneel, J. (2014). The social and economic mission of social enterprises: Dimensions, measurement, validation, and relation. Entrepreneurship Theory and Practice 39(5), 1051-1082.

Steyaert, C. \& Hjorth, D. eds. (2008). Entrepreneurship as social change: A third new movements in entrepreneurship book (Vol. 3). Edward Elgar Publishing.

Steyaert, C. \& Katz, J. (2004). Reclaiming the space of entrepreneurship in society: geographical, discursive and social dimensions. Entrepreneurship \& Regional Development, 16(3), 179-196.

Strauss, A., \& Corbin, J. (1998). Basics of qualitative research: Techniques and procedures for developing grounded theory. 2nd edition, Sage, Thousand Oaks, CA.

Sugarman, J., (2015). Neoliberalism and psychological ethics. Journal of Theoretical and Philosophical Psychology, 35(2), 103.

Tracey, P., Phillips, N., \& Haugh, H. (2005). Beyond philanthropy: Community enterprise as a basis for corporate citizenship. Journal of Business Ethics, 58(4), 327-344.

Watson, T. J. (2013). Entrepreneurial action and the Euro-American social science tradition: pragmatism, realism and looking beyond 'the entrepreneur'. Entrepreneurship \& Regional Development, 25(1-2), 16-33.

Welter, F. (2011). Contextualizing entrepreneurship - Conceptual challenges and ways forward. Entrepreneurship Theory and Practice 35(1), 165-184.

Wempe, J., (2005). Ethical entrepreneurship and fair trade. Journal of Business Ethics, 60(3), 211-220.

Wolcott, H. F. (1995). Making a study 'more' ethnographic. In J. Van Maanen, (eds.), Representation in Ethnography, (pp.86-111). Sage, Thousand Oaks, CA.

Yin, R. K. (2004). The case study anthology. Sage, Thousand Oaks, CA.

Zahra, S. A. (2007). Contextualizing theory building in entrepreneurship research. Journal of Business Venturing, 22(3), 443-452. 
Table 1: Description of Hutterite Colonies

\begin{tabular}{|c|c|c|c|c|c|c|c|c|}
\hline \multirow[t]{2}{*}{ Community } & \multirow[t]{2}{*}{ Established } & \multirow[t]{2}{*}{ Members } & \multirow[t]{2}{*}{$\begin{array}{c}\text { \#of } \\
\text { splits }\end{array}$} & \multirow[t]{2}{*}{ Core business } & \multicolumn{2}{|c|}{ New Enterprises } & \multicolumn{2}{|c|}{$\begin{array}{c}\text { Opportunities in } \\
\text { development }\end{array}$} \\
\hline & & & & & Less novel $^{1}$ & $\begin{array}{c}\text { More } \\
\text { novel }^{2}\end{array}$ & $\begin{array}{l}\text { Less } \\
\text { novel }\end{array}$ & $\begin{array}{l}\text { More } \\
\text { novel }\end{array}$ \\
\hline 1 & 1918 & 170 & $\begin{array}{l}4 \text { with } 1 \\
\text { underway }\end{array}$ & $\begin{array}{l}12,000 \text { acre grain, } 600 \\
\text { sows, } 14,000 \text { layer } \\
\text { quota, } 75 \text { dairy quota }\end{array}$ & $\begin{array}{l}\text { Feed mill, } \\
\text { Soybean } \\
\text { roaster, } \\
\text { Book store, }\end{array}$ & $\begin{array}{l}\text { Hutterite } \\
\text { directories }\end{array}$ & $\begin{array}{l}\text { Chinese } \\
\text { geese, } \\
\text { Rearing } \\
\text { Quail }\end{array}$ & $\begin{array}{l}\text { Straw } \\
\text { spreader }\end{array}$ \\
\hline 2 & 2003 & 88 & 0 & $\begin{array}{l}20,000 \text { acre grain, } 200 \\
\text { hog quota, layer and } \\
\text { chicken quota, beef } \\
\text { cattle }\end{array}$ & $\begin{array}{l}\text { Bag } \\
\text { recycling, } \\
\text { Bottle } \\
\text { recycling, }\end{array}$ & $\begin{array}{l}\text { Bubble } \\
\text { wrap }\end{array}$ & & $\begin{array}{l}\text { Solar } \\
\text { power }\end{array}$ \\
\hline 3 & 1954 & 140 & 2 & $\begin{array}{l}10,000 \text { acre grain, hog } \\
\text { quota, layer and dairy } \\
\text { operation }\end{array}$ & Laser cutting & $\begin{array}{l}\text { Chicken } \\
\text { feeders }\end{array}$ & $\begin{array}{l}\text { Grills, } \\
\text { Mfg } \\
\text { expansion }\end{array}$ & $\begin{array}{l}\text { Water } \\
\text { filtration }\end{array}$ \\
\hline 4 & 1965 & 78 & 2 & $\begin{array}{l}12,000 \text { acre grain, } \\
10,000 \text { layer quota, } \\
60 \text { hog quota, } 600 \\
\text { cow-calf operation, } \\
\text { dairy }\end{array}$ & $\begin{array}{l}\text { Custom } \\
\text { meat shop, } \\
\text { Greenhouse, } \\
\text { Hanging } \\
\text { baskets }\end{array}$ & & $\begin{array}{l}\text { Metal } \\
\text { furniture, } \\
\text { Crafts, } \\
\text { Own } \\
\text { brand }\end{array}$ & \\
\hline 5 & 1947 & 120 & 3 & $\begin{array}{l}8,000 \text { acres, hog } \\
\text { operation } 650 \\
\text { farrow to finish, } \\
9,500 \text { layers, dairy } \\
\text { cows, } 400 \text { hogs, } \\
200 \text { geese }\end{array}$ & $\begin{array}{l}\text { Metal } \\
\text { fabrication, } \\
\text { laser cutting, } \\
\text { Oilfield } \\
\text { parts }\end{array}$ & $\begin{array}{l}\text { Stackable } \\
\text { rocking } \\
\text { chairs }\end{array}$ & $\begin{array}{l}\mathrm{CNC} \\
\text { forming }\end{array}$ & $\begin{array}{l}\text { Custom } \\
\text { designed } \\
\text { parts and } \\
\text { equipment }\end{array}$ \\
\hline
\end{tabular}

\footnotetext{
${ }^{1}$ New ventures that are of the more standard form entrepreneurship - there is an already established market and clients

${ }^{2}$ New ventures that are more disruptive - markets and clients are not established
} 
Table 2: Data collection ${ }^{3}$

\begin{tabular}{|c|c|c|c|c|c|c|}
\hline Colony & & Position in colony & Entrepreneurial involvement & Gender & $\tilde{\text { Age }}$ & $\begin{array}{c} \\
\text { interviews }\end{array}$ \\
\hline \multirow[t]{6}{*}{1} & $\mathrm{~A}$ & Financial boss ${ }^{4}$ & "Front bench"5, feed mill, controls finances & $\mathrm{M}$ & 45 & 2 \\
\hline & $\mathrm{B}$ & Assistant minister & Developed bookstore, creates the directories & $\bar{M}$ & 45 & 2 \\
\hline & $\mathrm{C}$ & Retired & Influences and supports & $\mathrm{F}$ & 75 & 1 \\
\hline & $\mathrm{D}$ & General & Influences and supports & $\mathrm{F}$ & 45 & 1 \\
\hline & $\mathrm{E}$ & Chicken boss & developing straw spreader + quails & $\mathrm{M}$ & 40 & 1 \\
\hline & $\mathrm{F}$ & Mfg. shop boss & Helping with straw spreader & $\mathrm{M}$ & 35 & 1 \\
\hline \multirow[t]{2}{*}{2} & $\mathrm{~A}$ & Financial boss & Developing their solar power business & $\mathrm{M}$ & 50 & 1 \\
\hline & $\overline{\mathrm{B}}$ & Recycle plant boss & Developed the plastic bag recycling plant & $\bar{M}$ & 40 & 2 \\
\hline \multirow[t]{5}{*}{3} & A & Mfg.worker & Developing grills & $\mathrm{M}$ & 35 & 2 \\
\hline & $\mathrm{B}$ & Mfg. boss & Front bench, developed chicken feeders & $\bar{M}$ & 75 & 1 \\
\hline & $\mathrm{C}$ & Mfg. worker & Developing grills & $\mathrm{M}$ & 30 & 1 \\
\hline & $\mathrm{D}$ & German teacher & Front bench, developing water filtration & $\bar{M}$ & 45 & $2^{6}$ \\
\hline & $\mathrm{E}$ & Hog boss & Developing water filtration & $\mathrm{M}$ & 40 & 2 \\
\hline \multirow[t]{6}{*}{4} & $\mathrm{~A}$ & Head cook & Influences and supports & $\mathrm{F}$ & 70 & 1 \\
\hline & $\mathrm{B}$ & Dairy boss & Influences and supports & $\mathrm{M}$ & 40 & 1 \\
\hline & $\mathrm{C}$ & Gardener & Developing hanging baskets & $\mathrm{F}$ & 50 & 3 \\
\hline & $\mathrm{D}$ & General & Influences and supports & $\mathrm{F}$ & 20 & $1^{7}$ \\
\hline & $\mathrm{E}$ & Field boss & Front bench, brand, ventilation & $\mathrm{M}$ & 60 & 2 \\
\hline & $\mathrm{F}$ & Second Minister & Developed meat store & $\mathrm{M}$ & 40 & 2 \\
\hline \multirow[t]{3}{*}{5} & $\mathrm{~A}$ & Financial boss & Front bench, controls finances, wine, $\mathrm{mfg}$ & $\mathrm{M}$ & 65 & 2 \\
\hline & $\mathrm{B}$ & Mfg. boss & Mfg expansion, oilfield parts development & $\bar{M}$ & 35 & 1 \\
\hline & $\mathrm{C}$ & General & Stackable rocking chairs development & $\mathrm{F}$ & 65 & 1 \\
\hline \multirow{6}{*}{$\begin{array}{c}\text { External } \\
\text { informants }\end{array}$} & 1 & $\mathrm{Ag}$ consultant $\mathrm{C} 4$ & & $\mathrm{M}$ & 55 & 1 \\
\hline & 2 & Ag company rep $\mathrm{C} 2+4$ & & $\mathrm{~F}$ & 50 & 1 \\
\hline & 3 & Mgmt consultant -all & & $\bar{M}$ & 50 & 1 \\
\hline & 4 & Mgmt consultant -all & & $\mathrm{M}$ & 50 & 1 \\
\hline & 5 & Mgmt consultant -all & & $\mathrm{M}$ & 70 & 1 \\
\hline & 6 & Ex-hutterite & & $\mathrm{F}$ & 55 & 1 \\
\hline
\end{tabular}

${ }^{3}$ The quotes in the findings are coded according to this table. For instance " $1 A$ " refers to an informant A from colony 1 , EX3 refers to external informant \#3.

4 The Hutterites commonly assign positions using the term "boss"

${ }^{5}$ The "Front Bench" is the Hutterite's term for their executive team. This group of 3-5 men meet every morning and approve daily activities and requests.

${ }^{6}$ Interview done together with Hog boss, also his cousin

${ }^{7}$ Interview done together with gardener (her mom) 
Table 3 - Supporting data to show how moral obligations and ethics influence the communal enterprising process

\begin{tabular}{|c|c|c|c|c|}
\hline & Community-specific triggers & Community approval & Community-supported progression & Community-focused value creation \\
\hline $\begin{array}{l}\text { This shows us that } \\
\text { this stage of the } \\
\text { process is } \\
\text { influenced by: } \\
\text { The consequence } \\
\text { is: }\end{array}$ & $\begin{array}{l}\text { "Grandma and Auntie were } \\
\text { saying how much they loved } \\
\text { their rocking chairs then } \\
\text { complaining that they can't } \\
\text { take their rocking chairs when } \\
\text { they go visit. We want them to } \\
\text { be comfortable. We thought we } \\
\text { should build stackable rocking } \\
\text { chairs." (5B) } \\
\text { "For our [communal] lifestyle } \\
\text { to work everyone needs to have } \\
\text { a job. We need to be always } \\
\text { thinking how we can provide } \\
\text { jobs for all our people." (3D) }\end{array}$ & $\begin{array}{l}\text { idea is assessed by members of } \\
\text { the community who decide the } \\
\text { idea's potential for development. } \\
\text { "We've considered opportunities } \\
\text { but not pursued them. If it means } \\
\text { we need to have outside truckers } \\
\text { on to the colony. The colony } \\
\text { might make less but there is better } \\
\text { control over what our members } \\
\text { are exposed to." (1A) } \\
\text { "We look at things and evaluate } \\
\text { things well from a cultural } \\
\text { perspective....that measure of } \\
\text { success is more important than } \\
\text { financial success, we go into areas } \\
\text { (other than agriculture) not just } \\
\text { for financial success but to stay } \\
\text { self-sufficient." (3E) } \\
\text { "We consider if it provides a way } \\
\text { to keep our members busy and } \\
\text { happy, then if it is financially } \\
\text { beneficial, all the better." ( } 4 \mathrm{~F} \text { ) }\end{array}$ & $\begin{array}{l}\text { the community commits to } \\
\text { transforming idea into action and } \\
\text { develops the services and/or products } \\
\text { designed to create value } \\
\text { "Mentally, I own everything, so I am } \\
\text { invested in helping us succeed. Of } \\
\text { course, our system says I own } \\
\text { nothing, its all shared, but we look at } \\
\text { it like we own every part of the } \\
\text { community. Its not just a 9-5 job, if } \\
\text { someone is working on something } \\
\text { that could help our community, I'm } \\
\text { going to pitch in." (1F) } \\
\text { "We expect to fail the first time we } \\
\text { try something. Its okay, we support } \\
\text { that. Nobody loses their house or } \\
\text { can't feed their family if something } \\
\text { didn't work. Eventually it will get } \\
\text { worked out if it's God's will." (1D) }\end{array}$ & $\begin{array}{l}\text { The community develops the } \\
\text { structures and processes to allow for } \\
\text { growth and expansion } \\
\text { We built up a successful recycling } \\
\text { business...but it was too successful. } \\
\text { We had so much business we were } \\
\text { pulling ladies in to the plant. This is a } \\
\text { no-no for our way of life. This wasn't } \\
\text { the way for us so we got out of that } \\
\text { business and began to search for } \\
\text { something that fit us better." (2B) } \\
\text { "If the colony gets too big it causes } \\
\text { problems. People don't know each } \\
\text { other well enough and individualism } \\
\text { creeps in. That's not okay for us. } \\
\text { Everything we do, the choices we } \\
\text { make are so we stay true our beliefs. } \\
\text { We limit size so that community of } \\
\text { goods can work." (1B) } \\
\text { "There is a line we have come to in } \\
\text { the meat business. We have to make } \\
\text { decisions, do we renovate to conform } \\
\text { to new regulations are do we stay? } \\
\text { Do we want to do what everyone else } \\
\text { is doing? We have always been in } \\
\text { niches." (4D) }\end{array}$ \\
\hline
\end{tabular}

